\title{
GENUS Pothos: A REVIEW OF CHEMICAL CONSTITUENTS AND BIOLOGICAL ACTIVITIES
}

\author{
D. Dutta ${ }^{1,2}$, M. J. Bordoloi ${ }^{1}$ and N. K. Bhattacharyya ${ }^{2, 凶}$ \\ ${ }^{1}$ Chemical Sciences and Technology Division, CSIR-North East Institute of Science and \\ Technology, Jorhat-785007, (Assam) India \\ ${ }^{2}$ Department of Chemistry, Sikkim Manipal University (Sikkim Manipal Institute of \\ Technology), Majitar-737136, Rangpo, (Sikkim) India \\ ${ }^{\triangle}$ Corresponding Author: nkamalbhatt@gmail.com
}

\begin{abstract}
Pothos is a genus of flowering plants that belongs to the family Araceae. It plays a vital role in developing countries as folk medicine. Numerous compounds have been reported from Pothos, out of which some compounds have shown prominent bioactivities. The biological studies of this genus reported various activities including antimicrobial, anticancer, antioxidant, antipyretic, anti-diabetes, bronchodilator, burn wound healing, anticariogenic, thrombolytic etc. This review summarizes research carried out on chemical constituents with biological activities of Pothos genus to date.
\end{abstract}

Keywords: Pothos scandens, Pothos chinensis, Phytochemistry, Anticancer, Antimicrobial.

RASĀYAN J. Chem., Vol. 14, No.4, 2021

\section{INTRODUCTION}

The genus Pothos belongs to the family Araceae comprises 65 species of root-climbing lianes found in subtropical and tropical forests. It is distributed around the world from the Indian subcontinent to various islands of Indian Oceans and also native to China, Australia and Southeast Asia. ${ }^{1-2}$ Linnaeus $(1753,1763)$ and Schott (early in the $19^{\text {th }}$ century) described this genus as climbing aroids with bisexual flowers. ${ }^{3}$ It has been used in folk medicine throughout the world for various ethno medicinal uses. ${ }^{4-9}$ Various phytochemical studies on the genus reported that it contains both primary and secondary metabolites. The preliminary phytochemical screening reported several secondary metabolites from the different parts of this plant. ${ }^{10-15}$ Numerous compounds have been reported from this genus. The extracts, essential oils and the compounds isolated from various species of Pothos exhibited several biological activities, including antimicrobial, antioxidant, antipyretic, anti-diabetes, bronchodilator, burn wound healing, anticariogenic, thrombolytic, anticancer, peritoneal mast cell stabilization, hyaluronidase inhibitory, histamine release inhibiting activities. ${ }^{16-50}$ Despite the presence of several biological activities, only a few species from this genus were studied for the isolation of compounds. Moreover, the biological and other phytochemical studies in most of the species are still missing.

There is an increase in the trend of studying isolated compounds from a natural source in recent years due to their wide range of activities that could lead to the identification of promising lead compounds. ${ }^{51-53}$ In this review, the phytochemistry and biological activities of various species belonging to the genus Pothos are described. It includes a detailed classification of phytoconstituents and a systematic analysis of the biological activities reported in the literature till 2020. A total of 89 phytoconstituents comprised of alkaloids, terpenoids, phytosterols, flavonoids, glycosides, long-chain derivatives, and miscellaneous compounds are listed in this review.

\section{EXPERIMENTAL}

The authors collected data from Science Direct, SciFinder, Google Scholar, and PubMed related to Pothos genus. The authors reviewed and interpreted the articles of isolated compounds with biological activities against including antimicrobial, anticancer, antioxidant, antipyretic, anti-diabetes, bronchodilator, burn wound healing, anti-cariogenic and thrombolytic. 
RASĀYAN J. Chem.

Vol. 14 | No. 3 |2161-2170| October - December | 2021

\section{Chemical constituents}

\section{RESULTS AND DISCUSSION}

The genus Pothos has a rich source of alkaloids, flavonoids, terpenoids, coumarin, fatty acids, glycosides and phenolic acids. A total of 89 different types of compounds isolated from Pothos species are depicted in Fig.-1 to 11.

\section{Alkaloids}

Pothos reported the presence of alkaloids. 1,2,3,4-tetrahydro-3-carboxy-2 carboline (1) is a member of the class of beta-carboline alkaloid isolated from the plants $P$. scandens. ${ }^{10}$ Beta-carboline has a role as a plant metabolite and as a human urinary metabolite. (-)-serotobenine (2), indole-3-aldehyde (3) and Neoechinulin A (4) are indole alkaloid from the plants P. scandens and P. chinensis. ${ }^{12-13}$

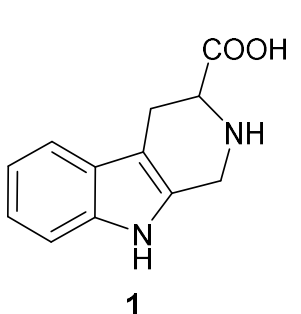

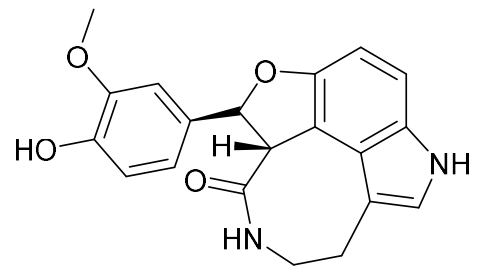

2

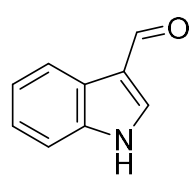

3

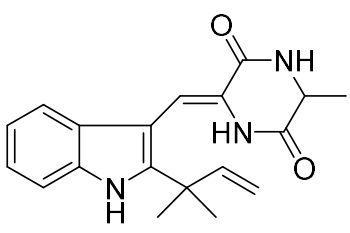

4

\section{Coumarins}

Fig.-1: Structures of Alkaloids (1-4)

Coumarins are phenolic substances that constitute fused benzene and $\alpha$-pyrone rings. Ji et al. isolated four coumarins including 7-methoxycoumarin (5), 7-hydroxy-8-methoxycoumarin (6), 6-hydroxy-7methoxycoumarin (7), and imperatorin (8) from P. chinensis. ${ }^{13}$<smiles>COc1ccc2ccc(=O)oc2c1</smiles>

5<smiles>COc1c(O)ccc2ccc(=O)oc12</smiles>

6<smiles>COc1cc2oc(=O)ccc2cc1O</smiles>

7<smiles>CC(C)=CCOc1c2occc2cc2ccc(=O)oc12</smiles>

8

\section{Fatty Acids}

Fig.-2: Structures of Coumarins (5-8)

Fatty acids are carboxylic acids containing aliphatic long-chain carbon atoms from C-4 to C-28 in saturated or unsaturated form. Palmitic acid (9), Oleic acid (10), Linoleic acid (11), 9,12,15ocatadecatrienoic acid (12), 13-Phenyltridecanoic acid (13), 13-(3',4'-Methylenedioxyphenyl)-tridecanoic acid (14) isolated from P. chinensis. ${ }^{15}$

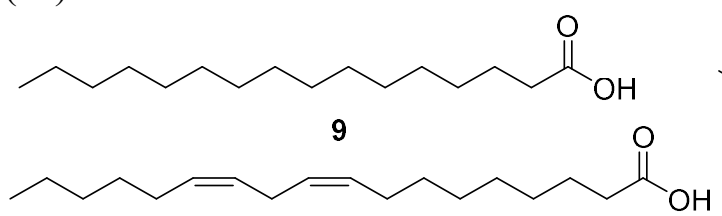

11<smiles>O=C(O)CCCCCCCCCCCCc1ccccc1</smiles>

13

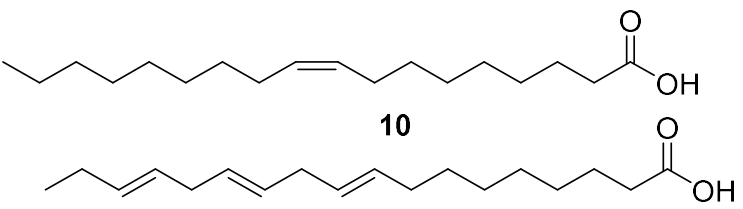

12

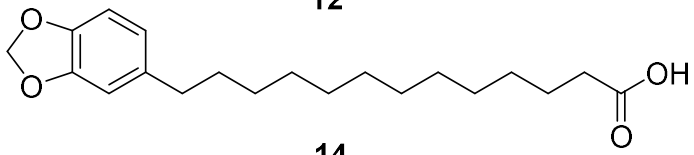

14

Fig.-3: Structures of Fatty acids (9-14)

\section{Flavonoids}

Several Flavones including Vicenin-2 (15), Neoschaftoside (16), Vitexin 2-O-xyloside (17), Scoparin 2O-xyloside (18) and liquiritigenin (19) were isolated from P. scandensand P. chinensis. ${ }^{4,10,14}$ In 2015, Muhit et al. have isolated flavonols including Kaempferol 3-O-gentiobioside (20), Quercetin 3-O- 
RASĀYAN J. Chem.

Vol. 14 | No. 3 |2161-2170| October - December | 2021

gentiobioside (21), Isorhamnetin 3-Ogentiobioside (22) from P. scandens. ${ }^{10}$ An isoflavone, Daidzein (23), was reported from $P$. chinensis. ${ }^{14}$ Several flavonoid glycosides including Vitexin (24), Vitexin 7-Oglucoside (isosaponarin, 25), Isovitexin 7-O-glucoside (saponarin, 26), Scoparin 7-O-glucoside (27), Isoscoparin 7-O-glucoside (28), Schaftoside (29), Isoschaftoside (30) and Chrysoeriol 7-Orhamnosylglucoside (31) have been isolated from $P$. chinensis. ${ }^{14}$<smiles>O=C1C[C@H](c2ccc(O)cc2)Oc2cc(O)ccc2C1=O</smiles><smiles>COc1cc(-c2cc(=O)c3c(O)cc(O)c(C4OC(CO)C(O)C(O)C4OC4OC[C@@H](O)C(O)C4O)c3o2)ccc1O</smiles><smiles>O=c1c(-c2ccc(O)cc2)coc2cc(O)ccc12</smiles>

23<smiles></smiles>

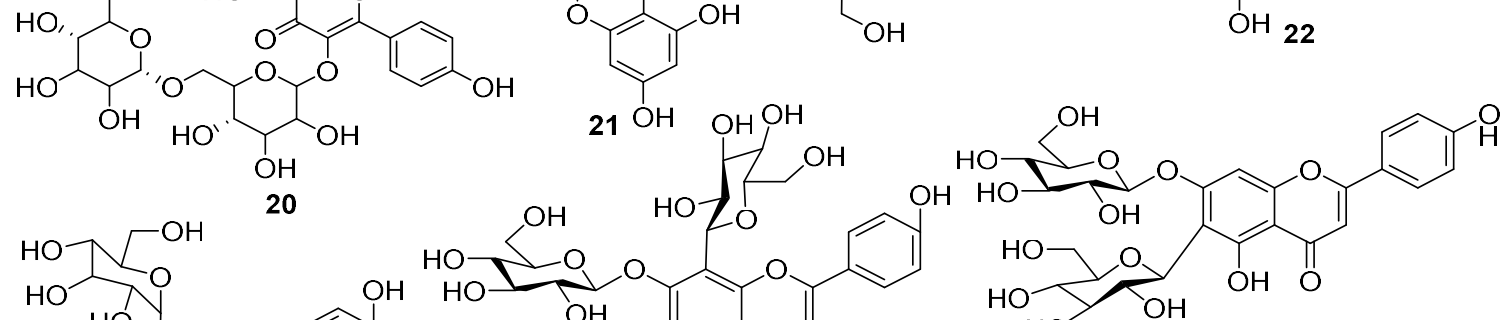

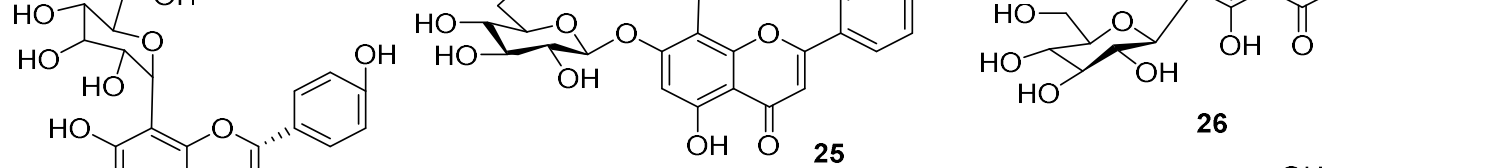<smiles>C=CC(=O)C(C)=C(C)C=C</smiles><smiles>COc1cc(C2=CCc3ccc(OC4OC(O)C(O)C(O)C(O)C4O)c(c3)O2)ccc1O</smiles>

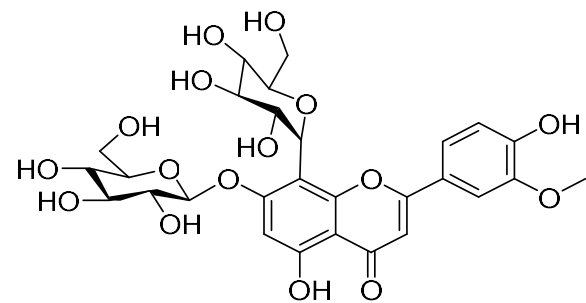

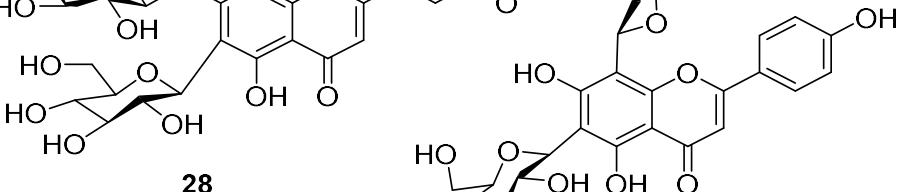

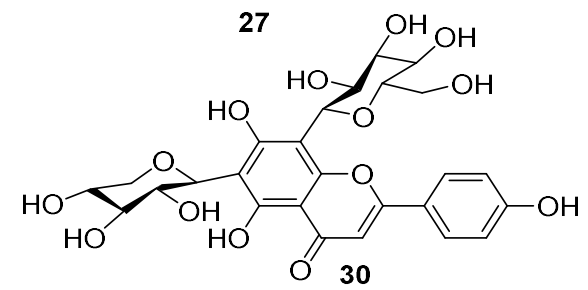

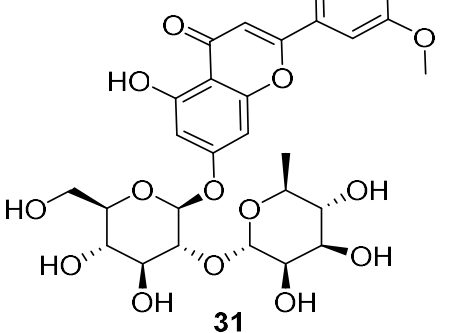

Fig.-4: Structures of Flavonoids (15-31) 
RASĀYAN J. Chem.

Vol. 14 | No. 3 |2161-2170| October - December | 2021

\section{Glycosides}

In glycoside structure, a sugar molecule is bound to another functional group via a glycosidic bond. They are essential in living organisms. Some glycosides including Zizybeoside I (32), Canthoside A (33) from $P$. scandens, and Berchemolide (34), and Prunasin (35) from P. chinensis have been reported. ${ }^{4,10} \mathrm{~A}$ Phenolic glycosides Markhamioside F (36) and a diketopiperazine, Eleutherazine B (syringin) (37) were reported from $P$. scandens. ${ }^{10}$

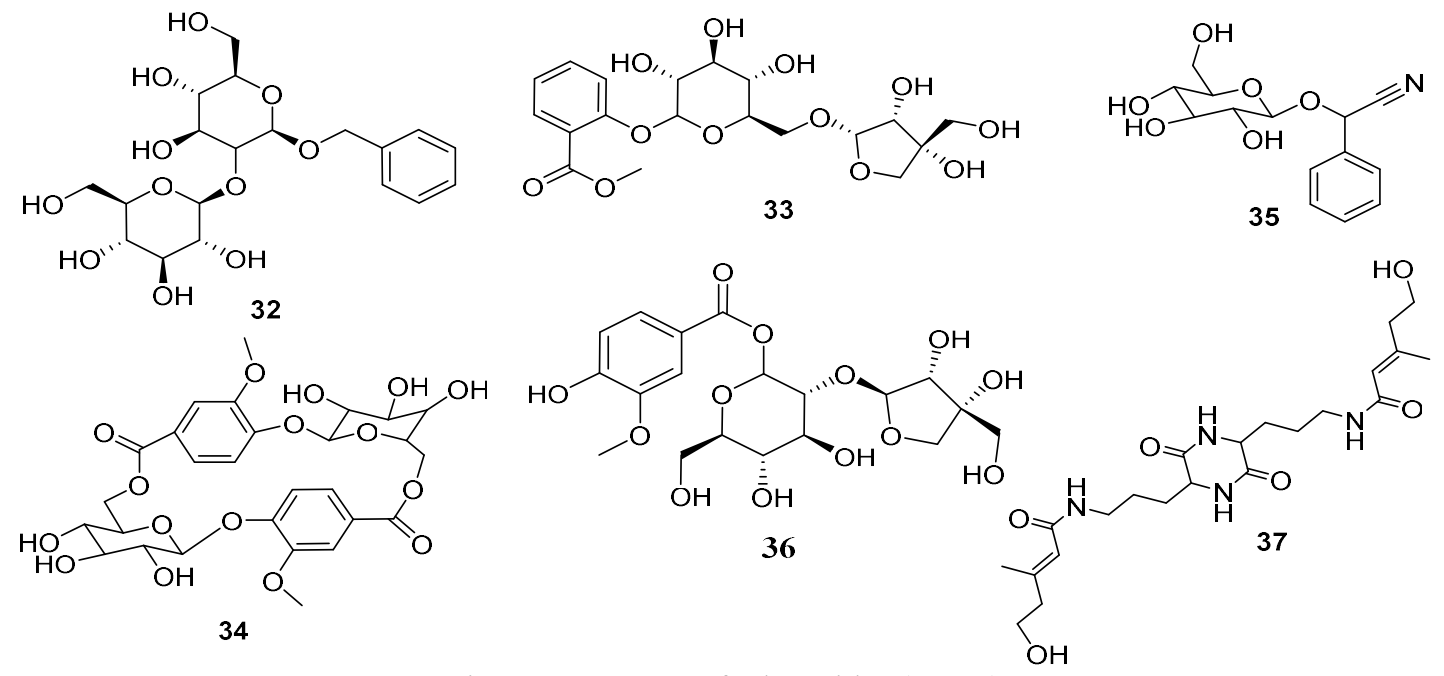

\section{Lignans}

Fig.-5: Structures of Glycosides (32-37)

Some lignans including (+)-syringaresinol (38), (-)-medioresinol (39), honokiol (40), hinokinin (41) were reported from $P$. scandens and $P$. chinensis. ${ }^{12,13,15}$

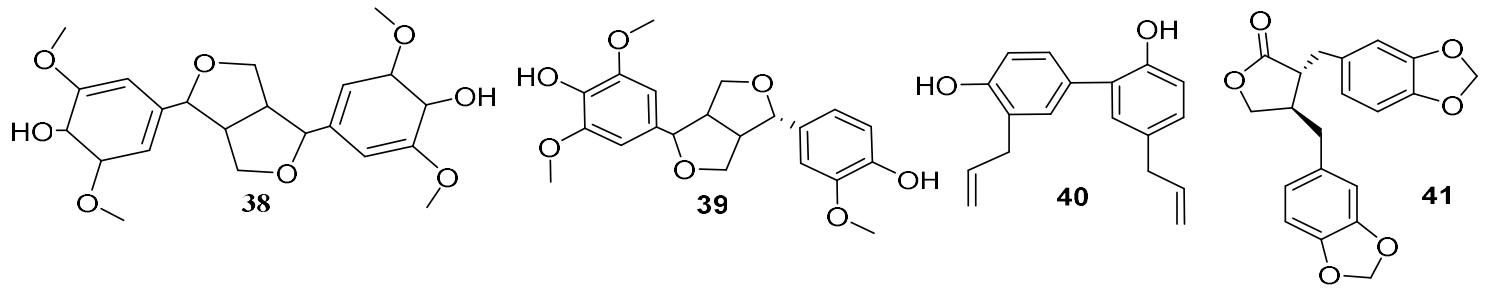

\section{Phenylamides}

Fig.-6: Structures of Lignans (38-41)

Phenylamides are the conjugated form of amines and phenolic acids. They are extensively distributed throughout the plant kingdom as a function of growth and development. In this class of compounds, Ntrans-cinnamoyltyramine (42), N-trans-feruloyltyramine (43) and N-trans-p-cumaroyltyramine (44) were reported from both the species $P$. scandens and $P$. chinensis. ${ }^{12-13}$ However, N-cis-p-coumaroyltyramine (45) and N-cis-feruloyltyramine (46) were reported from P. chinensis. ${ }^{13}$<smiles>O=C(/C=C/c1ccccc1)NCCc1ccc(O)cc1</smiles><smiles>O=C(/C=C/c1ccc(O)cc1)NCCc1ccc(O)cc1</smiles>

44<smiles>COc1cc(/C=C/C(=O)NCCc2ccc(O)cc2)ccc1O</smiles>

43<smiles>COc1cc(/C=C\C(=O)NCCc2ccc(O)cc2)ccc1O</smiles>

Fig.-7: Structures of Phenylamides (42-46) 


\section{RASĀYAN J. Chem.}

Vol. 14 | No. 3 |2161-2170| October - December | 2021

\section{Phenolic Acids}

Phenolic acids are aromatic acids composed of a phenolic ring and an organic carboxylic acid function $\left(\mathrm{C}_{6}-\mathrm{C}_{1}\right.$ skeleton). Several compounds belong to this class including Benzoic acid (47), p-anisic acid (48), p-toluic acid (49), p-hydroxybenzoic acid (50), vanillic acid (51), syringic acid (52), 3,4,5trimethoxycinnamic acid (53), 3, 4-dimethoxycinnamic acid (54), ferulic acid (55), p-hydroxycinnamic acid (56), p-hydroxybenzaldehyde (57), vanillin (58), syringaldehyde (59), p-methoxyphenyl-propionic acid (60), p-hydroxyphenyl-propionic acid (61), (R)-2-hydroxy-1(4-hydroxy-3-methoxypheny) propan-1one (62), p-hydroxyphenylethanol (63), and diisobutyl phthalate (64) were reported from P. chinensis. ${ }^{13}$<smiles>COc1ccc(C(=O)O)cc1</smiles><smiles>COc1ccc(/C=C/C(=O)O)cc1OC</smiles><smiles>COc1cc(/C=C/C(=O)O)ccc1O</smiles><smiles>O=C(O)/C=C/c1ccc(O)cc1</smiles><smiles>COc1cc(C=O)ccc1O</smiles><smiles>COc1cc(C=O)cc(OC)c1O</smiles><smiles>COc1ccc(CCC(=O)O)cc1</smiles><smiles>COc1cc(C(=O)C(C)O)ccc1O</smiles>
$\mathrm{HO}$<smiles>CC(C)COC(=O)c1ccccc1C(=O)OCC(C)C</smiles>

61

\section{Steroids}

Fig.-8: Structures of Phenolic acids (47-64)

Steroids are organic compounds composed of four fused rings including three six-member cyclohexane rings and one five-member cyclopentane ring. Some steroids including $\beta$-sitosterol (65), $\beta$-daucosterol (66), and 24-propylcholest-7-en-3-ol (67) were reported from P. chinensis. ${ }^{15}$ Muhit et al. isolated three stigmastane type steroid stigmast-4-en-3-one (68), stigmast-4,22-diene-3-one (69) and $\beta$-sitosterol glucoside (70) from P. scandens. ${ }^{11}$

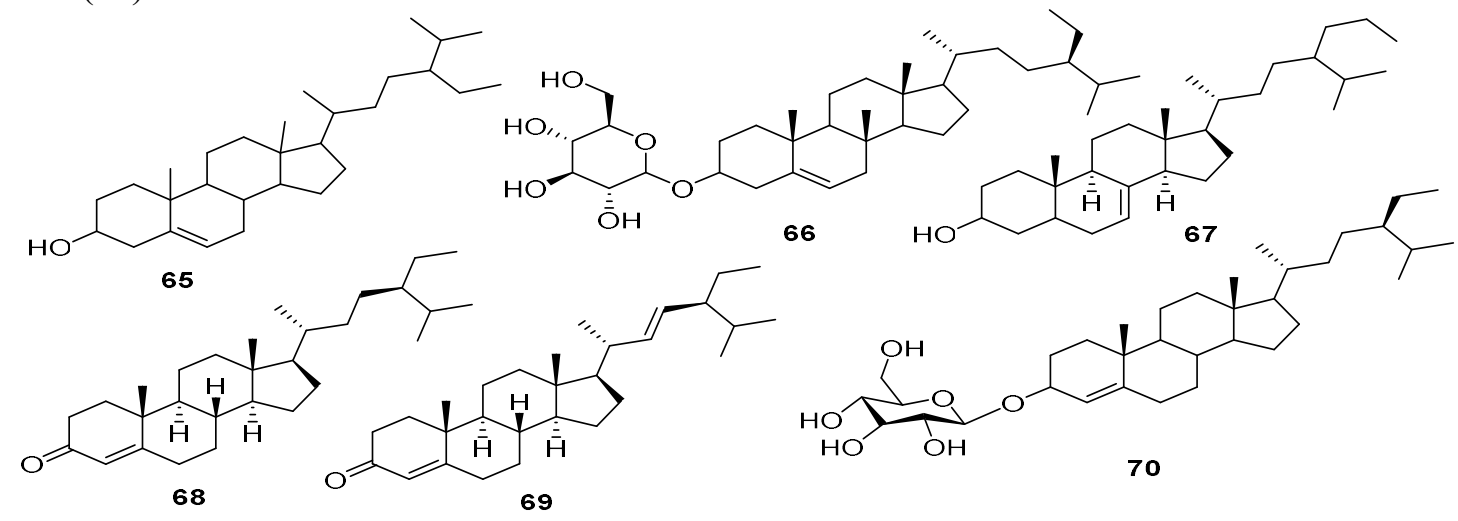

Fig.-9: Structures of Steroids (46-70)

\section{Terpenoids}

The genus Pothos is rich in terpenoids. Different classes of terpenoids like, hemiterpenene, diterpene, triterpene were reported from this genus. Hemiterpene glucosides including Pothobanoside A (71), Pothobanoside B (72), Pothobanoside C (73), and Canthoside B (74) were reported from P. scandens. ${ }^{10}$ Two Diterpenoids including Methyl Pothoscandensate (75) and (3ß)-ent-kaurane-3,16,17-triol (76) were reported from the whole plant of $P$. scandens. ${ }^{12}$ Muhit et al. isolated four cycloartane type triterpenoids 
RASĀYAN J. Chem.

Vol. 14 | No. 3 |2161-2170| October - December | 2021

triterpenoids including 24-methylenecycloartanol (77), 24-methylenecycloartenone (78), 24-encycloartenone (79), 24-methylenecycloartanylferulate (80) from P. scandens. ${ }^{11}$ A Norisoprenoid type triterpenoids, Dehydrovomifoliol (81) was also reported from P. chinensis. ${ }^{13}$ Two Carotenoids, also called tetraterpenoid, including Loliolide (82) and (+)-epiloliolide $\mathbf{( 8 3 )}$ were isolated from P. chinensis. ${ }^{13}$<smiles>COc1cc(C(=O)OC(O)C(O)OOCC=C(C)CO)ccc1O</smiles><smiles>COc1cc(C(=O)OCCOOCC=C(C)CO)c(O)c(OC)c1O</smiles>

72

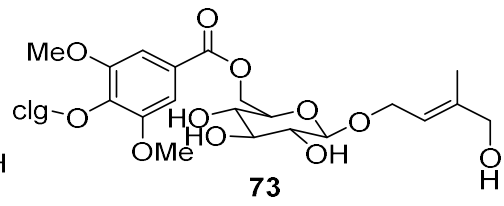<smiles>COc1cc(O[C@H]2O[C@H](CO[C@@H]3OC[C@](O)(CO)[C@H]3O)[C@@H](O)[C@H](O)[C@H]2O)cc(OC)c1O</smiles>

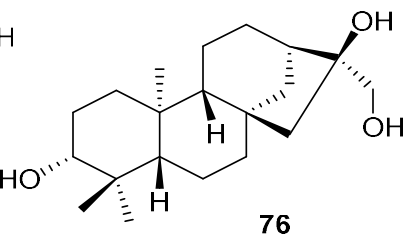

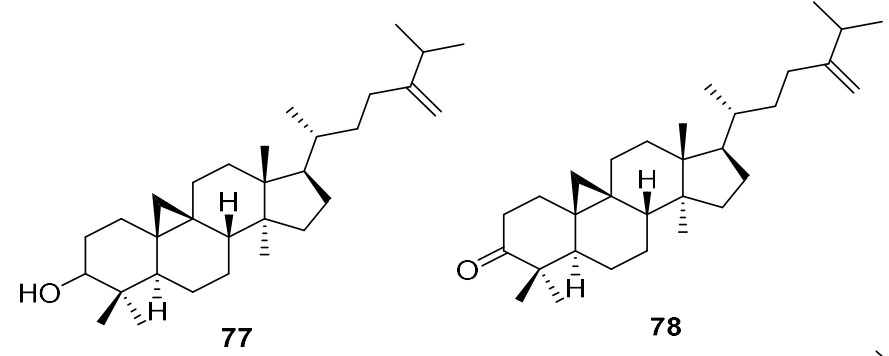

77<smiles>CC(=O)/C=C/[C@]1(O)C(C)=CC(=O)CC1(C)C</smiles>

79

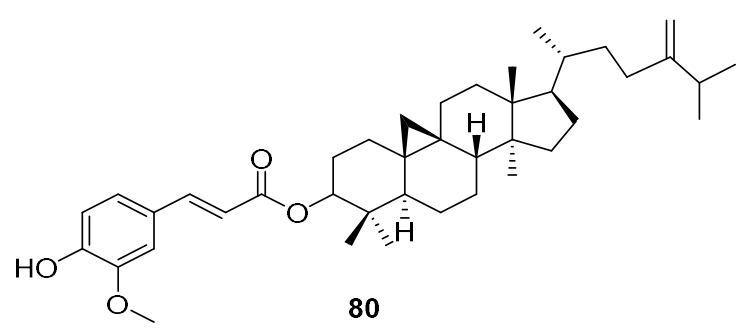

Fig.-10: Structures of Terpenoids (71-83)

\section{Miscellaneous}

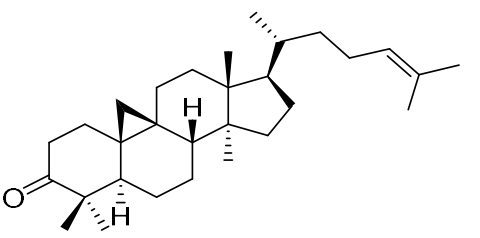

Three long-chain molecules including Hentriacontane (84), 1-monostearin (85), 1-monopalmitin (86) were isolated from $P$. chinensis. ${ }^{15}$ Parygul et al. isolated an aldehyde, 4-hydroxy-3,5dimethoxybenzaldehyde (87) from $P$. chinensis. ${ }^{4}$ A Phenyl isobutanol named Pothobanol (88) was reported from $P$. scandens. ${ }^{10}$ A tetracyclic phenol, Racemosol (89) was reported from P. chinensis.

\section{Biological Activities}

The biological studies revealed that isolated compounds and crude extracts of Pothos possess wide activities, such as antimicrobial, anticancer, antioxidant, antipyretic, anti-diabetes, bronchodilator, burn wound healing, anti-cariogenic, thrombolytic etc. in vitro and in vivo models.

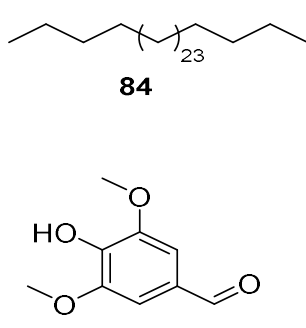

87<smiles>CCCCCCCCCCC(=O)OCC(O)CO</smiles><smiles>COCC(CO)C(O)c1ccccc1</smiles>

88<smiles>CCCCCCCCCCCCC(=O)OCC(O)CO</smiles>

86<smiles>COc1ccc(C2CC(C)(C)Oc3c(C)c(O)cc(CC[Se])c32)c(O)c1</smiles>

Fig.-11 Structures of Miscellaneous compounds (84-89) 
RASĀYAN J. Chem.

Vol. 14 | No. 3 |2161-2170| October - December | 2021

\section{Anticancer Activity}

The 50\% ethanol extract of $P$. scandens aerial parts exhibited cytotoxicity against MCF-7, a breast cancer cell line with $\mathrm{IC}_{50}$ value $90.18 \pm 5.20 \mu \mathrm{g} / \mathrm{ml}$ and also cell death of MCF-7 treated with the extract was due to the induction of apoptosis. ${ }^{20,36}$ According to Muhit et al., all the isolated compounds from $P$. scandens including compounds $(\mathbf{6 8 - 7 0}, \mathbf{7 7 - 8 0})$ exhibited mild to strong antiestrogenic activity against MCF-7 and T47D cancer cell lines which were compared with tamoxifen. ${ }^{11}$ Among these compounds, Compound 77 inhibited $90 \%$ of estradiol (E2)-induced cell proliferation at $0.01 \mu \mathrm{M}$ concentration in MCF-7 and T47D cell lines. Compound $\mathbf{8 0}$ exhibited $90 \%$ of estradiol (E2)-induced cell proliferation in MCF-7 cells at a concentration of $10.0 \mu \mathrm{M}$ whereas only $0.01 \mu \mathrm{M}$ was required for compound 69 for the same activity in T47D cell. In another study by Muhit et al. evaluated the anti-estrogenic activity of $P$. scandens towards MCF-7 and T47D cancer cell lines. ${ }^{10}$ The syringoyl derivatives exhibited anti-estrogenic activity than less oxygenated derivatives against cancer cell lines. Among the isolates, Pothobanoside B (72), pothobanoside C (73) and canthoside B (74) exhibited anti-estrogenic activities against cell lines MCF-7 and T47D. According to Yusuf et al. the methanolic extract of $P$. scandens leaf has strong cytotoxic activity with $\mathrm{LC}_{50}$ value of $14.195 \mu \mathrm{g} / \mathrm{ml}$ whereas standard vincristine sulphate showed $\mathrm{LC}_{50}$ value of $0.305 \mu \mathrm{g} / \mathrm{ml} .^{36}$ In a study by Jethinlalkhosh et al. reported the therapeutic effect of $P$. scandens on carbohydrate metabolizing enzymes, suggesting the species $P$. scandens as potential anticancer activity. ${ }^{21}$

\section{Antimicrobial Activity}

The in-vitro antimicrobial activity of $P$. scandens extracts against four microbial strains showed that the hexane and the ethyl acetate extracts were active against MRSA bacteria and Candida albicans with a zone of inhibition $6.59 \mathrm{~mm}$ and $8.30 \mathrm{~mm}$ respectively. ${ }^{23}$ The methanol extract of $P$. scandens showed that gram positive bacteria were inhibited at low concentrations $(250 \mu \mathrm{g} / \mathrm{ml}$ and $200 \mu \mathrm{g} / \mathrm{ml})$ than Gram negative bacteria $(400 \mu \mathrm{g} / \mathrm{ml}$ to $500 \mathrm{~g} / \mathrm{ml}) .{ }^{34}$ However, methanol extracts of $P$. scandens were reported antifungal activity against Aspergillus niger, Candida albicans, Microsporium gypsium, Chrysosporium keratinophilum, Trichophytum rubrum and Chrysosporium indicum. ${ }^{35}$

\section{Antioxidative Activity}

In a study by Jethinlalkhosh et al., $P$. scandens showed potent antioxidant activity with IC $_{50}$ value $(240.44 \pm 4.62 \mu \mathrm{g} / \mathrm{mL})$ for inhibiting hydroxyl radical. ${ }^{19}$ Sajeesh et al. reported in vitro antioxidant activity of ethanol and methanol extract of $P$. scandens root. ${ }^{33}$ Huang et al. studied antioxidant capacities of total flavonoids of $P$. chinensis by using the DPPH assays and reported that the DPPH scavenging rate of the flavonoids increases with concentration and time. ${ }^{37}$ In another study by Hemalatha et al. observed the higher antioxidant potential of the petroleum ether, ethyl acetate and chloroform extracts of the aerial roots of $P$. aurea in both DPPH scavenging assay and reducing capacity assay. ${ }^{16}$

\section{Antipyretic Activity}

In India, According to Lalitharani et al., $P$. scandens leaves have been employed to lower body heat and induce conception. ${ }^{25-26}$ Sajeesh et al. studied antipyretic activity of the methanolic extract of $P$. scandens L. root and reported a considerable decrease of temperature in pyrexia induced Wistar albino rats at a concentration of 200 and $400 \mathrm{mg} / \mathrm{Kg}$ doses compared with standard drug paracetamol. ${ }^{33}$

\section{Hyaluronidase Inhibitory Activity}

A strong hyaluronidase inhibitory activity was shown by flavonoids, luteolin, apigenin, and kaempferol, whereas moderate activity was shown by quercetin. Muhit et al. studied the hyaluronidase inhibitory activity of chemical constituents of $P$. scandens $\mathrm{L}^{10}{ }^{10}$ comparing positive control, mammalian hyaluronidase and rosmarinic acid. Among these compounds, nine compounds showed significant inhibition at $200 \mu \mathrm{M}$. Pothobanoside A (71) could be potential as an anti-tumor compound that showed significant activity with an inhibition rate of $46.7 \%$, whereas rosmarinic acid had an inhibition rate of 64.7\%. Moreover, Pothobanoside A (71), Pothobanoside B (72), Pothobanoside C (73), Pothobanol (88), Isoschaftoside (30), Vicenin-2 (15), Neoschaftoside (16) and Vitexin 2"'-O-xyloside (17) isolated from $P$. scandens have shown hyaluronidase inhibitory activity. 
RASĀYAN J. Chem.

Vol. 14 | No. 3 |2161-2170| October - December | 2021

\section{Other Activities}

Hossain et al. showed in vitro anti-diabetic activity of the methanol extract of $P$. scandens leave using $\alpha$ amylase enzyme inhibition technique with $\mathrm{IC}_{50}$ value of $1.49 \pm 0.190 \mathrm{mg} / \mathrm{mL}$ whereas standard drug acarbose showed $\mathrm{IC}_{50}$ value of $1.30 \pm 0.015 \mathrm{mg} / \mathrm{mL} .{ }^{17}$ In addition, the in vivo study of $P$. scandens by OGTT method using male Swiss albino mice in varying concentrations of the sample indicated the dosedependent anti- diabetic activity. ${ }^{17}$

The species $P$. scandens was found anti-cariogenic activity. Junaid et al. studied anticariogenic activity of the methanol extract of $P$. scandens leaf against some clinical isolates of Streptococcus mutans recovered from dental caries patients. ${ }^{18}$ They showed the inhibition of the growth with a zone of inhibition 1.1 to 1.9 by testing for their sensitivity to the extract by Agar well diffusion method.

Kim et al., evaluated the anti-inflammatory activity of ethanol extract of $P$. scandensin lipopolysaccharide-stimulated murine RAW 264.7 cells. ${ }^{24}$ The species $P$. scandens has been used traditionally in asthma. Hossain et al. revealed the bronchodilator activity of extract of $P$. scandens leaves, applied on Wister rat by counting the pre convulsive time showed $41.56 \%$ protection at $100 \mathrm{mg} / \mathrm{kg}$ dose with a comparison of standard drug Salbutamol. ${ }^{17}$

Blood clot formation leads to severe problems like anoxia, hypertension, stroke to the heart etc. ${ }^{28}$ According to Yusuf et al., the methanolic extract of $P$. scandens leaf showed thrombolytic activity of $19.451 \pm 1.711 \%$ lysis of clot whereas standard drug streptokinase (positive control) showed 69.480 \pm $2.651 \%$ and water showed (negative control) $3.0695 \pm 0.497 \%{ }^{36}$

Mohammed et al. prepared gel formulations of ethanolic extract of $P$. scandens $(4 \% \mathrm{w} / \mathrm{v})$ which showed a significant wound healing effect treated in animals. ${ }^{27}$ Sainuddin et al. prepared four different gel formulations A1, A2, A3 and A4 of ethanolic extract of $P$. scandens using Carbopol 940 in of 0.5, 1.0, 1.5 and $2.0 \%$. They found the second formulation (A2) to be transparent, non-greasy and stable but the third (A3) and fourth (A4) formulations to be translucent, tested for primary skin irritation and showed no signs of irritation. ${ }^{38}$

Pothobanoside C (73) and pothobanol (88) isolated from P. scandens have shown significant histamine release inhibition compared with positive control EGCgG3Me. ${ }^{10}$ Pothobanoside B (72) isolated from $P$. scandens have shown significant histamine release inhibitory from basophilic cells.

\section{Future Directions}

Although the genus Pothos has significant medicinal value, only a few species have been explored exhaustively for their chemical constituents and pharmacological activities till now. Further research with different species that have not been explored will provide new intuition in phytochemistry and its pharmacological properties. As illustrated in this review, Pothos is an abundant source of novel compounds which have shown promising bioactivities. The study of different biological properties to those isolated compounds with a wide range of activities could lead to the identification of promising lead compounds. Knowing the significance of the genus, in recent years, the scientific interest has increased greatly for further scientific exploration of this genus, to ascertain their therapeutic efficacy and commercial exploitation.

\section{CONCLUSION}

The genus Pothos have been utilized around the world in traditional remedy for decades. The genus provides an attractive bio resource for drug discovery research. The chemical constituents of this genus have shown promising several biological activities and would be potential for further research. Although the genus has great traditional value and also several biological activities but the detailed phytochemical study so far has not been explored. However, only two species $P$. scandens and $P$. chinensis were studied for isolation of bioactive compounds.

\section{ACKNOWLEDGEMENT}

All the authors would like to thank Director, SMIT, Majitar, Sikkim and the Director, CSIR-North East Institute of Science and Technology, Jorhat, Assam for providing research facilities. 


\section{RASĀYAN $J$. Chem.}

Vol. 14 | No. 3 |2161-2170| October - December | 2021

\section{REFERENCES}

1. P.C. Boyce, Thailand Forest Buletin (Botany), 37, 15(2009).

2. N.H. Sojeetra, R. Acharya, European Journal of Medicinal Plants, 31, 22(2020), https://doi.org/10.9734/ejmp/2020/v31i530234

3. P.C. Boyce, A. Hay, Telopea, 9, 449(2002).

4. H.M. Kamal, S. Bidur, S.M. Kaium, K. Mazumder, International Journal of Pharmacognosy and Phytochemical Research, 7, 1202(2015).

5. A.H. Thanda, S.M. Myint, A.M, Mu, T.Z. Min, Natural Products Communication, 11, 353(2016), https://doi.org/10.1177/1934578X1601100310

6. M.R. Deepa, S. Dharmapal, P.S. Udayan, Journal of Medicinal Plants Studies, 4, 149(2016).

7. K.S. Dogra, S. Chauhan, J.S. Jalal, Journal of Medicinal Plants Research, 9, 851(2015), https://doi.org/10.5897/JMPR2015.5890

8. P.C. Houghton, I.M. Osibogun, Journal of Ethnopharmacology, 39, 1(1993), https://doi.org/10.1016/0378-8741(93)90047-9

9. U.N. Kanjilal, P.C. Kanjilal, A. Das, C. Purkayastha, Flora of Assam, 1 (1936).

10. M.A. Muhit, M. Izumikawa, K. Umehara, H. Noguchi, Phytochemistry, 121, 30(2015), https://doi.org/10.1016/j.phytochem.2015.10.009

11. M.A. Muhit, K. Umehara, N. Sharmin, H. Noguchi, Dhaka University Journal of Pharmaceutical Sciences, 18, 93(2019), https://doi.org/10.3329/dujps.v18i1.41896

12. H. Liu, J.L. Bi, Y.H. Wang, W. Gu, Y. Su, F. Liu, S. Yang, G. Hu, J. Luo, G. Yin, C. Long, Helvetica Chimica Acta, 95 (2012), https://doi.org/10.1002/HLCA.201200006

13. M.C. Ji, D.L. Guo, S.Y. Jiang, S.J. Xiao, Y. Zhou, L.S. Ding, Tianran Chanwu Yanjiu Yu Kaifa, 27, 609(2015).

14. T. Iwashina, C. Peng, G. Kokubugata, Bulletin of National Museum of Nature and Sciences Series B, 36, 27(2010).

15. H. Sun, G. Ding, B. Song, T. Zhang, W.S. Feng, Z.M. Zou, Journal of Chinese Pharmaceutical Sciences, 50, 1186(2015), https://doi.org/10.11669/cpj.2015.14.005

16. S. Hemalatha, P. Lalitha, P. Arulpriya, Pharma Chemica, 2, 84(2010).

17. M.K. Hossain, B. Seal, M.A.K., Siddiki, K. Mazumder, International Journal of Pharmacognosy and Phytochemical Research, 7, 1202(2015).

18. S. Junaid, N. Dileep, K.N. Rakesh, G.M. Pavithra, K.S. Vinayaka, T.R.P. Kekuda, Journal of Applied Pharmaceutical Sciences, 3, 20(2013), https://doi.org/10.7324/JAPS.2013.30304

19. J.P Jethinlalkhosh, A. Arun, A.D. Victor, Asian Journal of Pharmaceutical and Clinical Research, 9 (2016a).

20. J.P Jethinlalkhosh, S.S. NAIR, P. Praveena, A.D.D. Victor, International Journal Pharmacy Pharmaceutical Sciences, 8, 274(2016b).

21. J.P. Jethinlalkhosh, P. Praveena, A.D.D. Victor, Indian Journal of Pharmaceutical Education Research, 51, 418(2017a), https://doi.org/10.5530/ijper.51.3.70

22. J.P. Jethinlalkhosh, P. Praveena, A.D.D. Victor, Journal of Applied Science and Engineering Methodology, 3, 522(2017b).

23. B.S.B. Karunathilaka, Y.A. Priyadarshana, S. Rajapakse, L. Jayasinghe, A. Wickramasinghe, RSU International Research Conference, Rangsit University, Thailand (2016), https://doi.org/10.14458/RSU.res.2016.15

24. J. Kim, S.H. Jeong, W. Lee, H. Min, Food Science and Biotechnology, 26, 791(2017), https://doi.org/10.1007/s10068-017-0093-3

25. V.R. Lalitharani, A. Mohan, A. Maruthupandian, International Journal of Phytomedicine, 2 , 277(2010a).

26. S. Lalitharani, V.R. Mohan, G.S. Regini, Journal of Economic and Taxonomic Botany, 34, 472(2010b).

27. H.K.P. Mohammed, S. Hanan, R. Saraswathi, M.G. Prasad, N. Chandini, Asian Pacific Journal of Tropical Medicine, 3, 988(2010), https://doi.org/10.1016/S1995-7645(11)60015-1 


\section{RASĀYAN J. Chem.}

Vol. 14 | No. 3 |2161-2170| October - December | 2021

28. F. Hussain, A. Islam, L. Bulbul, M.R. Moghal, M.S. Hossain, Ancient Science Life, 33, 162(2014), https://doi.org/10.4103/0257-7941.144620

29. K.K.N. Nair, K. Yesodharan, K.K. Unni, KFRI Research Report, 124, 106(1997).

30. H. Sato, H. Kawagishi, T. Nishimura, S. Yoneyama, Y. Yoshimoto, S. Sakamura, A. Furusaki, S. Katsuragi, T. Sainuddin, Webmed Central, 1 (2010).

31. S. Sultana, H.M. Asif, N. Akhtar, K. Ahmad, Asia Pacific Journal of Tropical Disease, 5, S202(2015), https://doi.org/10.1016/S2222-1808(15)60890-8

32. S.G. Shu, L. Heng, P.C. Boyce, Flora of China, 23, 6(2010).

33. T. Sajeesh, K. Aruachalam, T. Parimelazhagan, Asia Pacific Journal of Tropical Medicine, 4, 889(2011), https://doi.org/10.1016/S1995-7645(11)60214-9

34. K.S. Vinayaka, T.R.P. Kekuda, N. Rajkumar, M.B. Chandrashekar, S. Banakar, S.V. Hegde, Research Journal of Pharmacy and Technology, 2, 850(2009a).

35. K.S. Vinayaka, S.V. Hegde, S. Banakar, T.R.P. Kekuda, Journal of Natural Products, 5, 146(2009b).

36. A.T.M. Yusuf, M.M.U. Rashid, M.M. Hassan, M.A. Sayeed, M.A. Jainul, Journal of Pharmacognosy and Phytochemistry, 2, 193(2013).

37. O. Huang, X. He, Y. Huang, Shipin Gongye, 35, 162(2014).

38. T. Sainuddin, M.K.P. Haneefa, Webmed Central, Wound Healing, 1, WMC001344 (2010), https://doi.org/10.9754/journal.wmc.2010.001344

39. A.K. Das, B.K. Dutta, G.D. Sharma, Indian Journal of Traditional Knowledge, 7, 446(2008).

40. P. Rethy, B. Singh, R. Kagyung, P.R. Gajurel, Indian Journal of Traditional Knowledge, 9, 61(2010).

41. S. Lee, C. Xiao, S. Pei, Journal of Ethnopharmacology, 117, 362(2008), https://doi.org/10.1016/j.jep.2008.02.001

42. S. Kumar, K. Chaitanya, A.J. Semotiuk, V. Krishna, Ethnobotany Research and Applications, 18, 1(2019), https://doi.org/10.32859/era.18.4.1-112

43. M.S. Savinaya, S.S. Patil, J. Narayana, V. Krishna, International Journal of Herbal Medicine, 4, 124(2016).

44. R.A. DeFilipps, G.A. Krupnick, The medicinal plants of Myanmar, PhytoKeys, 102, 1(2018).

45. J. Barukial, J.N. Sarmah, International Journal of Medicinal and Aromatic Plants, 1, 203(2011).

46. M. Ayyanar, S. Ignacimuthu, Journal of Ethnopharmacology, 102, 246(2005), https://doi.org/10.1016/j.jep.2005.06.020

47. P. Poovathur, S. Joseph, International Journal of Advanced Science and Research, 1, 24(2016).

48. R.C. Srivastava, Indian Journal of Traditional Knowledge, 9, 26(2010).

49. M.K. Haneefa, S.K. Hanan, G.P. Mohanta, C. Nayar, Journal of Pharmaceutical Sciences and Research, 6, 63(2014).

50. M.K. Haneefa, S.K. Hanan, G.P. Mohanta, R. Saraswathi, Asian Pacific Journal of Tropical Medicine, 3, 988(2010), https://doi.org/10.1016/S1995-7645(11)60015-1

51. V. Mierza, Rosidah, G. Haro, D. Suryanto, Rasayan Journal of Chemistry, 13, 1894(2020), https://doi.org/10.31788/RJC.2020.1335864

52. D. Handayani1, T. Wahyuningsih, Rustini, M.A. Artasasta, A. E. Putra, P. Proksch, Rasayan Journal of Chemistry, 13, 327(2020), https://doi.org/10.31788/RJC.2020.1315589

53. E.E. Aung, A. N. Kristanti, N. S. Aminah, Y. Takaya, R. Ramadhan, H. T. Aung, Rasayan Journal of Chemistry, 14, 312(2021), https://doi.org/10.31788/RJC.2021.1416106

[RJC-6353/2020] 